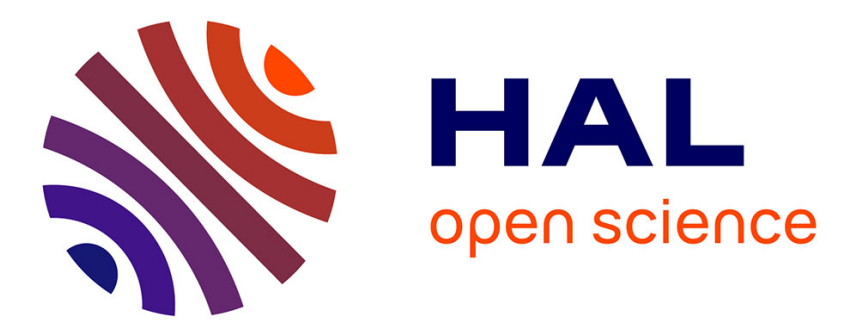

\title{
Heat transfer problems for the production of hydrogen from geothermal energy
}

\author{
J. Sigurvinsson, C. Mansilla Pellen, B. Arnasson, André Bontemps, Alain \\ Maréchal, T. Sigfusson, F. Werkoff
}

\section{- To cite this version:}

J. Sigurvinsson, C. Mansilla Pellen, B. Arnasson, André Bontemps, Alain Maréchal, et al.. Heat transfer problems for the production of hydrogen from geothermal energy. Energy Conversion and Management, 2007, 47 (20), pp.3543-3551. 10.1016/j.enconman.2006.03.012 . hal-00189138

\section{HAL Id: hal-00189138 https://hal.science/hal-00189138}

Submitted on 11 Feb 2020

HAL is a multi-disciplinary open access archive for the deposit and dissemination of scientific research documents, whether they are published or not. The documents may come from teaching and research institutions in France or abroad, or from public or private research centers.
L'archive ouverte pluridisciplinaire HAL, est destinée au dépôt et à la diffusion de documents scientifiques de niveau recherche, publiés ou non, émanant des établissements d'enseignement et de recherche français ou étrangers, des laboratoires publics ou privés.

\section{(c)(1)}

Distributed under a Creative Commons Attribution| 4.0 International License 


\title{
Heat transfer problems for the production of hydrogen from geothermal energy
}

\author{
J. Sigurvinsson a,*, C. Mansilla a, B. Arnason ${ }^{\mathrm{b}}$, A. Bontemps ${ }^{\mathrm{c}, \mathrm{d}}$, \\ A. Maréchal ${ }^{\mathrm{c}}$, T.I. Sigfusson ${ }^{\mathrm{b}}$, F. Werkoff ${ }^{\mathrm{a}}$ \\ ${ }^{\text {a } C E A / D E N / D M 2 S / S E R M A / L T E D ~ C E A / S A C L A Y ~(B a t . ~ 470)-91191 ~ G i f-S u r-Y v e t t e ~ C e d e x, ~ F r a n c e ~}$ \\ ${ }^{\mathrm{b}}$ University of Iceland, Science Institute, Dunhagi 3,107, Reykjavik, Iceland \\ ${ }^{\mathrm{c}}$ Universite Joseph Fourier, BP No 5338041 Grenoble Cedex 9, France \\ ${ }^{\mathrm{d}}$ CealDrt/Dten/Greth 11, Rue des Martyrs 38054 Grenoble Cedex 9, France
}

Electrolysis at low temperature is currently used to produce Hydrogen. From a thermodynamic point of view, it is possible to improve the performance of electrolysis while functioning at high temperature (high temperature electrolysis: HTE). That makes it possible to reduce energy consumption but requires a part of the energy necessary for the dissociation of water to be in the form of thermal energy.

A collaboration between France and Iceland aims at studying and then validating the possibilities of producing hydrogen with HTE coupled with a geothermal source. The influence of the exit temperature on the cost of energy consumption of the drilling well is detailed.

To vaporize the water to the electrolyser, it should be possible to use the same technology currently used in the Icelandic geothermal context for producing electricity by using a steam turbine cycle. For heating the steam up to the temperature needed at the entrance of the electrolyser three kinds of heat exchangers could be used, according to specific temperature intervals.

Keywords: Hydrogen; Geothermal energy; High temperature electrolysis; Heat transfer; Iceland

\section{Introduction}

The use of hydrogen as a substitute to hydrocarbons, is currently the object of many research and development tasks in the world. To be sustainable, a hydrogen production process must be carried out without consumption of raw materials other than water and driven by energy produced without greenhouse gas emissions. Electrolysis at low temperature carried out using sustainably produced electricity satisfies these constraints and is currently used to produce hydrogen. However, today it is more expensive than the process of producing hydrogen by steam reforming of natural gas, which presents a double disadvantage since it consumes natural gas and rejects carbon dioxide. From a thermodynamic point of view, it is possible to improve the performance of

\footnotetext{
* Corresponding author. Tel.: +33 169086358; fax: +33 169082977.

E-mail addresses: JS206070@AQUILON.CEA.FR, jonthor@jonthor.com (J. Sigurvinsson).
} 


\section{Nomenclature}

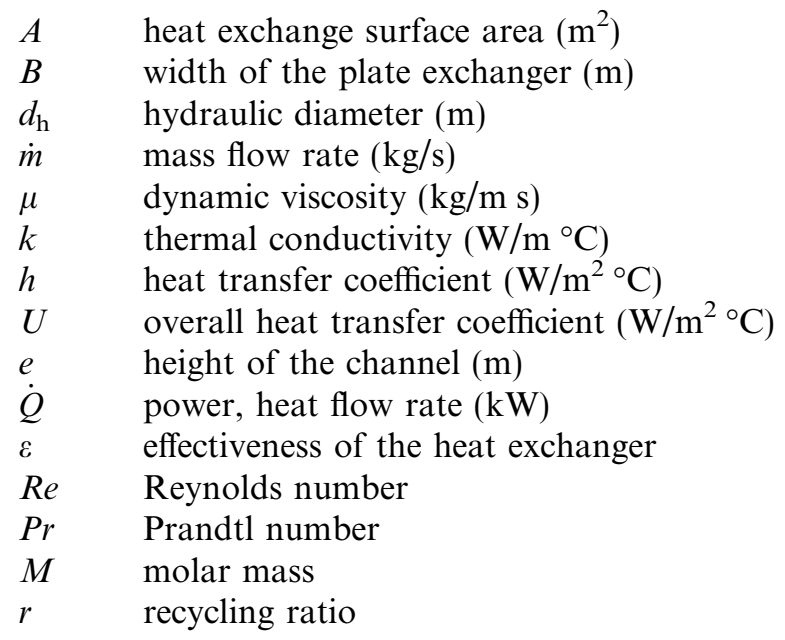

\section{Subscripts}

$\begin{array}{ll}1 & \text { steam no } 1 \\ 2 & \text { steam no } 2 \\ 3 & \text { steam no } 3 \\ 4 & \text { steam no } 4 \\ \mathrm{HT} & \text { high temperature } \\ \mathrm{MT} & \text { medium temperature } \\ \mathrm{LT} & \text { low temperature } \\ \mathrm{H}_{2} & \text { properties of hydrogen } \\ \mathrm{O}_{2} & \text { properties of oxygen } \\ \mathrm{H}_{2} \mathrm{O} & \text { properties of water }\end{array}$

electrolysis while functioning at high temperature (HTE). That makes it possible to reduce energy consumption but requires a part of the energy necessary for the dissociation of water to be in the form of thermal energy.

Recent HTE research programs have profited from new financings, mainly within the Generation IV International Forum framework for developing long term nuclear reactors [1]. The forum considers the possibilities of using nuclear energy, particularly high temperature helium cooled reactors (HTR) which include the possibility of producing hydrogen.

A collaboration between France and Iceland aims at studying and then validating the possibilities of producing hydrogen with HTE coupled with a geothermal source. Its principal objective is the production of hydrogen by HTE coupled with a geothermal source in the Icelandic context. The goal is to build a $5 \mathrm{~kW}$ e prototype on the site of Nesjavellir, which is $20 \mathrm{~km}$ from Reykjavik [2]. Iceland brings its competences and its experience in the field of geothermal drilling, the exploitation, the transport and the transformation (in particular in electric power) of steam extracted at the geothermal sources. France brings its scientific knowledge and its industrial experience on the thermal problems of heat transfers for various ranges of temperatures, as well as the results of the research and development on Solid Oxide Fuel Cells, which works in reverse of the electrolysers at high temperature.

\subsection{Hydrogen from geothermal energy}

The economically harnessable geothermal energy in Iceland has been estimated at approximately $200 \mathrm{TW}$ h/year, of which only $1 \%$ has been harnessed up to now. Assuming the same technology used in 
Iceland today to produce electricity from geothermal steam, the $200 \mathrm{TW}$ h/year could be used for the production of $20 \mathrm{TW}$ h/year of electricity, or $17 \mathrm{TW}$ h/year of hydrogen [3].

\subsection{The Jules Verne project}

The Jules Verne project which was the subject of a convention on behalf of the two states, marks the first stage of the collaboration between France and Iceland. Its principal objective is a techno-economic study of the production of hydrogen by HTE coupled with a geothermal source in Iceland. The estimated duration of the project is from 2003 to 2005 . The following stage of collaboration will carry on into a start up program, GEYSER, dated around 2009 to build a $5 \mathrm{~kW}$ e prototype on the site of Nesjavellir.

In Section 2, we will present the present status of the Nesjavellir plant, and the present heat exchangers used there. Section 3 will be devoted to a discussion on the influence of the heat source temperature (HTR or geothermal) and the presentation of the prospects of deeper drilling. In Section 4 requirements for the heat exchanger network for HTE will be provided, taking into account the particularities of the GEYSER project.

\section{Present status of the Nesjavellir plant}

The geothermal plant in Nesjavellir (Fig. 1) currently produces 90 MW of electric energy and 400 MW of thermal energy. The thermal energy is used to heat up water through a heat exchanger after which it is distributed for house heating and general hot water consumption. The heat exchanger is a pipe counter current exchanger (Fig. 2). There is no need for special anti-corrosion techniques because of the low levels of oxygen in the geothermal steam.

Because of high volcanic activity, the strata of rock under Nesjavellir are relatively young. Rock temperature is highest next to volcanic fractures. At sea level, the temperature there is approximately $100{ }^{\circ} \mathrm{C}$. At $2 \mathrm{~km}$ down, it exceeds $350^{\circ} \mathrm{C}$. In Iceland the drilling wells are usually from 1 to $3 \mathrm{~km}$ deep with pressures from 3 to $7 \mathrm{MPa}$.

For electricity production in Nesjavellir, steam is extracted at $3 \mathrm{MPa}$ and vaporized to $1.3 \mathrm{MPa}$ at a temperature of about $200{ }^{\circ} \mathrm{C}$. Before entering the turbines steam and water are separated, with minerals exiting with the water and incompressible gases $0.4 \%$ of the mass, continuing with the steam.

In Iceland, geothermal energy accounts for 39\% of the total consumption, oil accounts for 38\%, hydro $19 \%$ and finally coal $4 \%$ [3]. This percentage is so large because all house heating and consumer hot water comes from geothermal resources. The two main processes for producing electricity are the hydro and geothermal

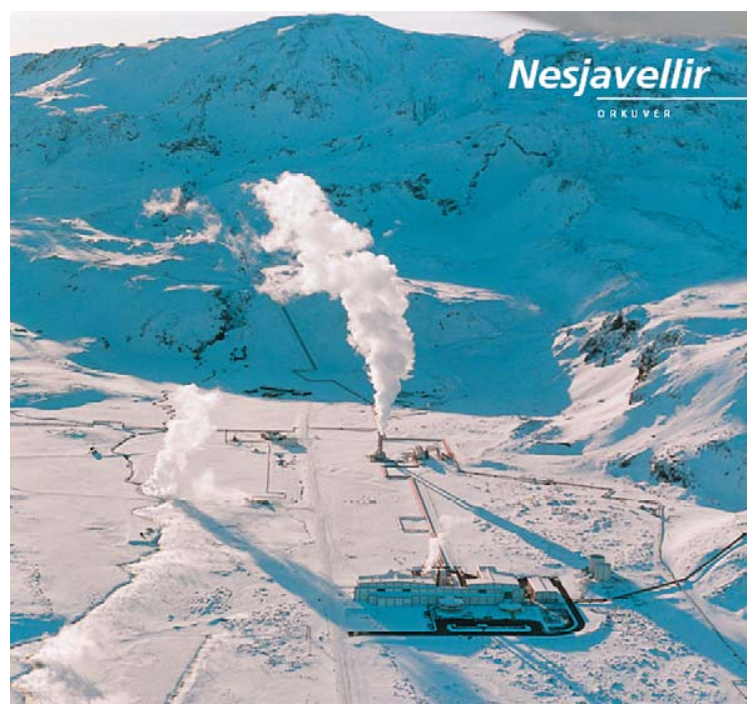

Fig. 1. The Nesjavellir plant. 


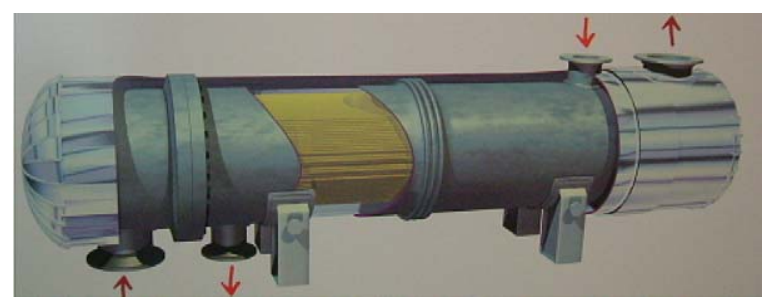

Fig. 2. Heating water heat exchanger at Nesjavellir.

energy processes. The electricity production capacity of the national electricity company Landsvirkjun in Iceland is over $1200 \mathrm{MW}$ today and will increase by $600 \mathrm{MW}$ when the newest hydro electric power plant at Karahnjukar will be ready. While most of the electricity is produced by hydro energy, around $10 \%$ is produced by geothermal energy.

Hydrogen has been produced largely from alkaline electrolysis in Iceland for over 50 years, mainly for ammonia used in fertilizer production. A novelty in utilisation happened with the introduction of the ECTOS [4] project in 2003, where part of the public transport system in Iceland is run on hydrogen. The hydrogen for the ECTOS project is produced by alkaline electrolysers technology from Norsk Hydro.

\section{The influence of the temperature of the heat source}

High temperature electrolysis (HTE) is an alternative to the conventional electrolysis process. Some of the energy required to split the water is provided as heat instead of electricity, thus reducing the overall energy required and improving process efficiency. Because the conversion efficiency of heat to electricity is low compared to using the heat directly, the energy efficiency can be improved by providing the energy to the system in the form of heat rather than electricity.

In Iceland the cost of extracting thermal energy from a geothermal source is only about $10 \%$ of the cost of electricity produced.

$$
\mathrm{kW} \mathrm{h} \mathrm{h}_{\text {(th-geo })}=0.1 \mathrm{~kW} \mathrm{~h} \mathrm{e}_{(\mathrm{e} \text {-geo })} .
$$

For HTR the expected efficiency of electricity production is $50 \%$ hence we can assume that the cost of thermal energy for HTR is $50 \%$ of the price of electricity.

$$
\mathrm{kW} \mathrm{h}_{(\text {th-HTR })}=0.5 \mathrm{~kW} \mathrm{~h} \mathrm{e}_{(\mathrm{HTR})}
$$

Thermal energy from a geothermal source is very inexpensive compared to thermal energy from a HTR. In the Icelandic context steam could be supplied at $200{ }^{\circ} \mathrm{C}$. According to Jonsson et al. [9] only $3.8 \mathrm{~kW} \mathrm{~h}(\mathrm{e}) / \mathrm{N} \mathrm{m}^{3}$ $\mathrm{H}_{2}$ is needed with a thermal input of $200{ }^{\circ} \mathrm{C}$, compared with about $4.5 \mathrm{~kW} \mathrm{~h}_{(\mathrm{e})} / \mathrm{N} \mathrm{m}^{3} \mathrm{H}_{2}$ in conventional electrolysers. Electricity price to industry in Iceland is approximately $0.014 € / \mathrm{kW} \mathrm{h} \mathrm{compared} \mathrm{to} 0.0284 € / \mathrm{kW} \mathrm{h} \mathrm{[5]}$ (Table 1) for middle term electricity produced by nuclear reactors in France. When this price difference is taken into account the difference between producing hydrogen by HTE in Iceland and France is evident, regarding only the cost of vaporizing and heating water to the operating temperature of the electrolyser (Fig. 3).

Although only $200{ }^{\circ} \mathrm{C}$ of thermal input is possible today, that could change. Recent research performed by Landsvirkjun on deep drilling in Iceland show a possibility of extracting $500-600{ }^{\circ} \mathrm{C}$ steam at a depth of 4-5 km. At this time deep drilling is purely experimental but could become a possibility within the next 10

Table 1

Energy prices, geothermal/HTR

\begin{tabular}{ll}
\hline$/ \mathrm{kW} \mathrm{h}_{(\mathrm{e})}$ Iceland & 0.014 \\
$€ / \mathrm{kW} \mathrm{h}_{(\mathrm{e})}$ France & 0.0284 \\
$€ / \mathrm{kW} \mathrm{h}_{\text {(th) }}$ Iceland & 0.0014 \\
$€ / \mathrm{kW} \mathrm{h}_{(\text {th) }}$ France & 0.0142
\end{tabular}




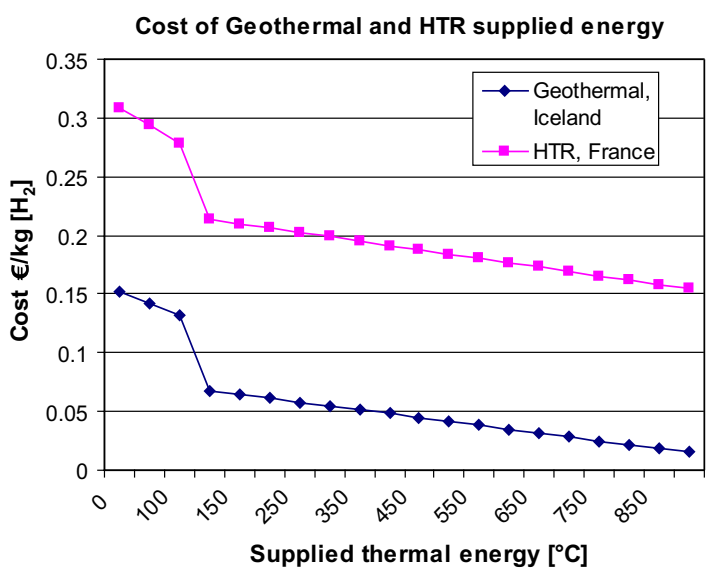

Fig. 3. Cost of vaporizing and heating water to the required temperature for the electrolyser.

years. The influence of the exit temperature on the cost of the energy consumption of the drilling well is obvious.

A recent evolution of the HTR concept is the very high temperature reactor (VHTR) for which the helium temperature at the outlet of the reactor core would be up to $950-1000{ }^{\circ} \mathrm{C}$. With this kind of heat source the endothermal solution, discussed in the next section, would be possible with no extra heating by electricity.

\section{The heat exchanger network}

\subsection{Operating modes for HTE}

There are three possible operating modes for HTE depending on the energy balance at the electrolyser level: endothermal, isothermal and exothermal.

\subsubsection{Endothermal}

The temperature of the steam decreases from the input of the electrolyser to the output. This corresponds to the best energy efficiency but worst production cost because an endothermal electrolyser is much more expensive than an exothermal one.

\subsubsection{Isothermal}

The temperature of the steam is the same at the input as at the output. The energy efficiency is better than in the exothermal case but the electrolyser cost still outweighs better efficiency.

\subsubsection{Exothermal}

The temperature of the steam increases from the input of the electrolyser to the output. This corresponds to the worst energy efficiency but best production cost because an exothermal electrolyser investment cost is the lowest of the three possibilities [6]. The exothermal mode is best suited for the geothermal context since the input temperature is only $200{ }^{\circ} \mathrm{C}$.

\subsection{Heat exchangers}

The entering temperature of the electrolyser could be between $750{ }^{\circ} \mathrm{C}$ and $900{ }^{\circ} \mathrm{C}$. To be effective from a thermodynamic point of view, the HTE requires a recovery of the heat contained at the exit from the electrolyser. Heat needs to be recovered in parallel from oxygen and from the hydrogen-steam mixture, in order to heat the steam in contact with the geothermal source, up to the desired temperature at the entry of the electrolyser. 


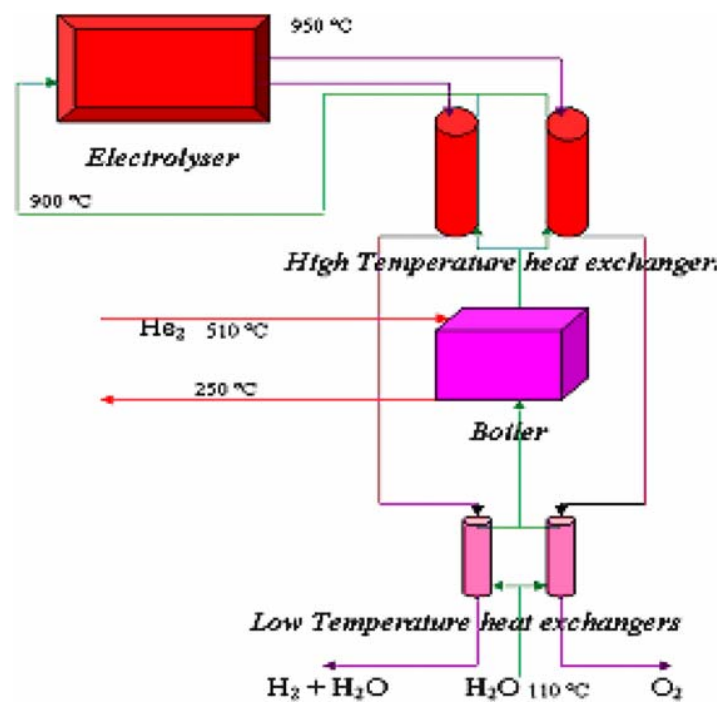

Fig. 4. Exothermal heat exchanger network coupled with an HTR.

When designing a heat exchanger network for high temperature steam electrolysis, the results should not be the same if the heat source is geothermal or if it is heat produced by a high temperature reactor. This is due to the fact that physical properties are different: the heat is not supplied at the same temperature; and several economic parameters are different too. Indeed, the cost of thermal energy is much lower in the case of geothermal, and the discount rate should not be the same. The high temperature heat exchanger network has been optimised with a techno-economic method using genetic algorithms [7]. The principle of the method is minimizing an objective function: the total cost, which includes investment costs as well as operating costs.

Fig. 4 shows the heat exchanger network for an exothermal HTE coupled with an HTR. The heat exchanger network adapted to geothermal heat (Fig. 8) will differ from HTR at the thermal source with the addition of more types of exchangers specified for different temperature levels. The heat exchangers can be classified into three categories according to the ranges of temperatures.

Since we have a wide range of temperatures, we need different heat exchangers and materials. All of the suggested heat exchangers are counter-current flow and primary surface heat exchangers. The temperature intervals are defined as follows:

\subsection{Medium temperature}

Stainless steel heat exchanger $\left(<650{ }^{\circ} \mathrm{C}\right)$ capable of $7 \mathrm{MPa}$ up to $300^{\circ} \mathrm{C}$ (Fig. 5).

\subsection{High temperature}

Nickel based heat exchanger $\left(650^{\circ} \mathrm{C}<T<850^{\circ} \mathrm{C}\right)$ capable of $1-2 \mathrm{MPa}$ at $650{ }^{\circ} \mathrm{C}$, currently under testing (Fig. 6).

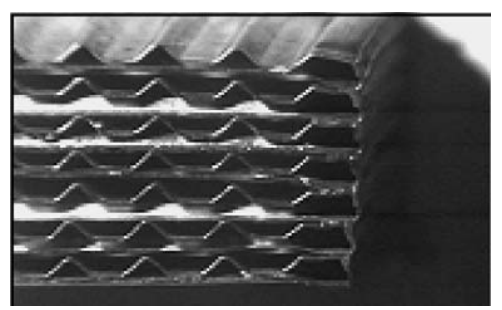

Fig. 5. Medium temperature exchanger. 


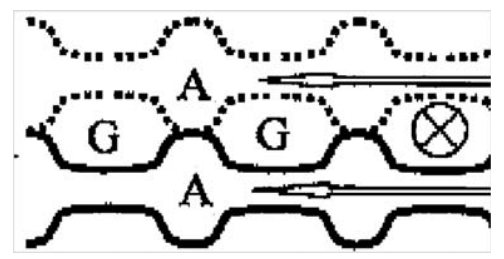

Fig. 6. High temperature exchanger.

\subsection{Very high temperature}

Ceramic based heat exchanger $\left(>850^{\circ} \mathrm{C}\right)$ capable of $10-50 \mathrm{MPa}$ at $850^{\circ} \mathrm{C}$, more investigation on what material and which heat exchanger to use for this temperature level is needed (Fig. 7).

The heat exchanger suggested for the $>850{ }^{\circ} \mathrm{C}$ temperature level is still being tested and further detail will be available soon. However, it could also be possible to operate the electrolyser at lower than $850{ }^{\circ} \mathrm{C}$ temperatures using existing technology.

In assuming that plate heat exchangers with primary surfaces are used to insure a high effectiveness, the overall heat transfer coefficient can be derived as follows, neglecting the conduction thermal resistance:

$$
U=\frac{1}{\frac{1}{h_{1}}+\frac{1}{h_{2}}},
$$

where $h_{1}$ and $h_{2}$ are the heat transfer coefficients for the hot (1) and cold (2) side, respectively, and given by

$$
h_{i}=\frac{N u_{i} \lambda_{i}}{d_{\mathrm{h}}}, \quad i=1,2,
$$

where $d_{\mathrm{h}}=2 e$ is the hydraulic diameter and where $N u_{i}$ is the Nusselt number which can be calculated for specific plates by [8]

$$
N u_{i}=0.0254 R e_{i}^{0.638} \operatorname{Pr}_{i}^{1 / 3} .
$$

$\operatorname{Pr}_{i}$ being the Prandtl number and $R e_{i}$ being the Reynolds number calculated from

$$
R e_{i}=\frac{2 \dot{m}_{i}}{\mu_{i} B}
$$

where $B$ is the plate width, $\dot{m}_{i}$ the mass flow rate and $\mu_{i}$ the dynamic viscosity of the fluid in the hot $(i=1)$ and in the cold $(i=2)$ side, respectively.

These here above equations allow us to determine $U$ and to calculate either the heat flow rate $\dot{Q}$ or the heat exchange area $A$ using the logarithmic mean temperature difference $\Delta T_{\mathrm{ml}}$ following the classical equation

$$
\dot{Q}=U A \Delta T_{\mathrm{ml}} \text {. }
$$

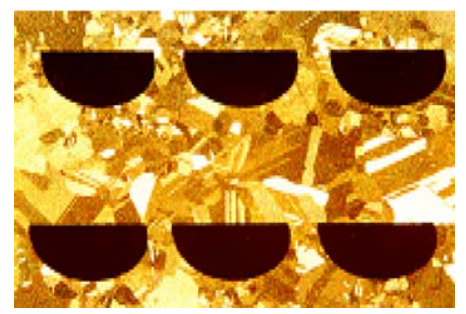

Fig. 7. Very high temperature exchanger. 


\section{Heat exchanger network}

The geothermal heat exchanger network is presented in Fig. 8. Writing the heat and mass balance equations for each heat exchanger and relating it to their heat transfer rates calculated with the Eq. (9), the characteristics of the heat exchanger network can be optimised to minimize total cost. In this calculus, a recycling of the gases must be taken into account. The output of the electrolyser is firstly oxygen and secondly a mixture of hydrogen and steam. This mixture is dependent on the recycling ratio $r$. Not all the water is electrolysed and the number $r$ indicates this ratio of unelectrolysed water. The mixture of water and hydrogen is defined as follows (see Table 2):

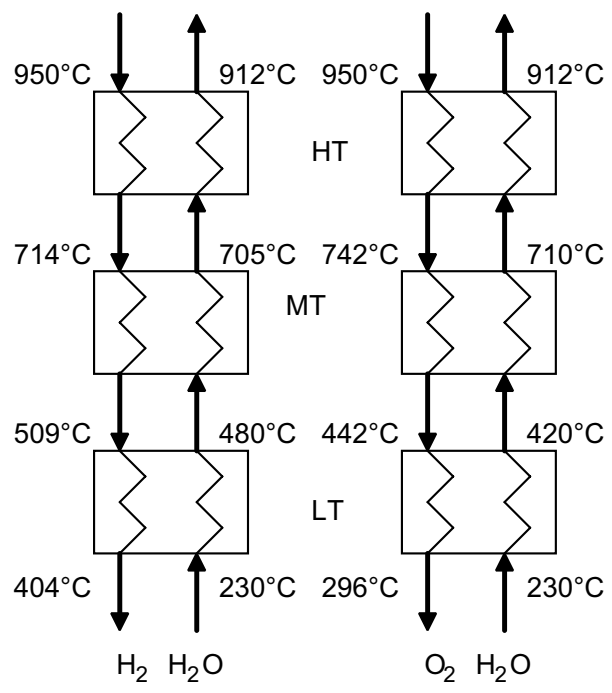

Fig. 8. Geothermal heat exchanger network.

Table 2

Heat exchanger characteristics

\begin{tabular}{lr}
\hline$\dot{m}_{\mathrm{H}_{2} \mathrm{O}}(\mathrm{kg} / \mathrm{s})$ & 15.4 \\
$\dot{m}_{1 \mathrm{H}_{2}}(\mathrm{~kg} / \mathrm{s})$ & 6.2 \\
$\dot{m}_{2 \mathrm{H}_{2}}(\mathrm{~kg} / \mathrm{s})$ & 12.1 \\
$\dot{m}_{1 \mathrm{O}_{2}}(\mathrm{~kg} / \mathrm{s})$ & 9.2 \\
$\dot{m}_{2 \mathrm{O}_{2}}(\mathrm{~kg} / \mathrm{s})$ & 3.3 \\
$Q_{\mathrm{H}_{2} \mathrm{HT}}(\mathrm{kW})$ & 6049 \\
$Q_{\mathrm{H}_{2} \mathrm{MT}}(\mathrm{kW})$ & 6323 \\
$Q_{\mathrm{H}_{2} \mathrm{LT}}(\mathrm{kW})$ & 6895 \\
$Q_{\mathrm{O}_{2} \mathrm{HT}}(\mathrm{kW})$ & 1587 \\
$Q_{\mathrm{O}_{2} \mathrm{MT}}(\mathrm{kW})$ & 2193 \\
$Q_{\mathrm{O}_{2} \mathrm{LT}}(\mathrm{kW})$ & 1404 \\
$Q_{\mathrm{total}}(\mathrm{kW})$ & 24456 \\
$\varepsilon_{\mathrm{H}_{2} \mathrm{HT}}$ & 0.845 \\
$\varepsilon_{\mathrm{O}_{2} \mathrm{HT}}$ & 0.841 \\
$\varepsilon_{\mathrm{H}_{2} \mathrm{MT}}$ & 0.893 \\
$\varepsilon_{\mathrm{O} 2 \mathrm{MT}}$ & 0.900 \\
$\varepsilon_{\mathrm{H}_{2} \mathrm{LT}}$ & \\
$\varepsilon_{\mathrm{O}_{2} \mathrm{LT}}$ & \\
$4072<R e<23897$ & 2.897 \\
$6.36 \times 10^{-4}<\operatorname{Pr}<9.73 \times 10^{-3}$ & 0.897 \\
$U \sim 1\left(\mathrm{~kW} / \mathrm{m}^{2}{ }^{\circ} \mathrm{C}\right)$ &
\end{tabular}




$$
\begin{aligned}
& \dot{m}_{1, \mathrm{H}_{2}}=(1-r) \cdot \dot{m}_{\mathrm{H}_{2} \mathrm{O}} \cdot \frac{M_{\mathrm{H}_{2}}}{M_{\mathrm{H}_{2} \mathrm{O}}}+r \cdot \dot{m}_{\mathrm{H}_{2} \mathrm{O}}, \\
& \dot{m}_{1, \mathrm{O}_{2}}=\frac{(1-r)}{2} \cdot \dot{m}_{\mathrm{H}_{2} \mathrm{O}} \cdot \frac{M_{\mathrm{O}_{2}}}{M_{\mathrm{H}_{2} \mathrm{O}}} .
\end{aligned}
$$

The main characteristics of the heat exchanger network are presented in Table 2 and Fig. 8 when it is optimised to minimize the total cost.

In Fig. 8 the heat exchangers are labelled as follows: high temperature (HT), medium temperature (MT), low temperature (LT).

\section{Conclusion}

The production of hydrogen by high temperature electrolysis appears to be very promising mainly in the Icelandic geothermal context. One key to the HTE efficiency is the recuperation of heat at the outlet of the electrolyser by heat exchangers. The needed heat exchangers are under test for medium and low temperatures but for over $850^{\circ} \mathrm{C}$ they still need further developing.

\section{References}

[1] Generation IV. Generation IV roadmap crosscutting economics R\&D scope report. GIF-007-00, December2002. Available from: http://gif.inel.gov/roadmap/pdfs/007_crosscutting_economics_r-d_scope_report.pdf 2002.

[2] GEYSER. High temperature electrolysis at CEA and comparison with other hydrogen production technologies, IEA Workshop on high temperature electrolyse, San Antonio, 2004.

[3] Arnason Bragi, Sigfusson TI. Iceland as a future hydrogen economy. Int J Hydrogen Energy 2000;25:389-94.

[4] ECTOS. Available from: http://www.newenergy.is/ectos.asp. Ecological City Transport System, 2003.

[5] DGEMP-DIDEME. Coûts de référence de la production électrique, 2003.

[6] Pinteaux T. Analyse des potentialités de production d'hydrogéne par électrolyse de la vapeur d'eau á haute température en couplage avec un réacteur nucléaire de type High Temperature Reactor (HTR). DRT, Université Joseph Fourier, 2002.

[7] Mansilla C, Sigurvinsson J, Bontemps A, Maréchal A, Werkoff F. Heat management for hydrogen production by high temperature steam electrolysis. In: 18th International conference on efficiency, cost, optimization, simulation and environmental impact of energy systems, 2005.

[8] GRETh. Pertes de pression et transfert de chaleur dans les echangeurs a plaques en simple phase. Manuel technique du GRETh, 1999.

[9] Arnason B, Sigfusson TI, Jonsson VK. New concepts in hydrogen production in Iceland. Int J Hydrogen Energy 1993;18:915-9. 